\title{
Sunni Islamists: From Syria to the Umma, and back
}

\author{
Version auteur d'un chapiter publié dans Matthieu Cimino (dir.), Exploring Syria's \\ Borders and Boundaries. State, Nation and Identities (Springer, 2020): 221-242.
}

\section{Thomas Pierret, Aix Marseille Université, CNRS, IREMAM, Aix-en-Provence, France}

Islamists, the established wisdom has it, define political bonds in religious terms, hence are supposedly loyal to the global community of Muslims (umma) rather than to the nation, unless pragmatic adaptation forces them to undertake a nationalist turn. ${ }^{1}$ Accordingly, it has been argued that the Syrian Muslim Brotherhood (SMB), Syria's main Islamist group since its establishment in 1946, provided a distinctly Islamic contribution to the post-independence debate about the best way to redeem the perceived historical injustice resulting from "artificial" colonial borders:

Whereas the Syrian Social National Party championed the vision of regional nationalism, basing its logic on geography as the great definer of nationhood, the Baath anchored its ideology in the principles of language and history. The Muslim Brotherhood, however, raised the issue of religion as the most logical and enduring bond among people, proclaiming the ideal of the unity of the Muslim world as the desired shape of the future. ${ }^{2}$

However intuitive, this typology is inaccurate. It has already been demonstrated, for other contexts, that early Islamists approached loyalty to the nation-state, the Arab nation, and the Umma, in terms of complementarity, rather than contradiction. ${ }^{3}$ The SMB even went further than that by giving precedence to Syrian and Arab identities over Islamic unity. The organisation remained remarkably faithful to this orientation into the $21^{\text {st }}$ century despite its conflict with the Ba'thist regime, and despite the rise of wholly anti-nationalist views among Islamist circles from the 1960s onwards. As for the 2011 revolution and the conflict that ensued, they had ambivalent consequences for the way Syrian Islamists defined the borders of the ideal polity: while the radical rejection of nationhood achieved unprecedented prominence with the rise of the Islamic State, the legitimacy of Syrianhood gradually consolidated among an increasingly broad range of Islamists including "revisionist Jihadis" from the Ahrar alSham Islamic Movement. ${ }^{4}$

In this chapter, I make sense of the Syrian Islamists' evolving relation to Syria borders by focusing on two main variables. The first is the ideological and political context, which defines the boundaries of acceptable and relevant discourses about the territorial boundaries of the ideal polity. The second is the position of each of the Islamist groups under consideration with regard to the idea of participation in Syrian politics. So, having made a strategic choice in favour of participation, the SMB concluded that the best way to maximise political relevance was to embrace the dominant discourse among Syrian political actors, that is, Syria-centric Arab nationalism. Although the latter ideology declined in the last two decades of the $20^{\text {th }}$ century, its proponents - within the regime and the non-Islamist opposition - remained key interlocutors for the SMB, which by that time had become an exiled organisation craving for returning to Syria. ${ }^{5}$

Outright rejection of nationalism, on the other hand, has been championed by Islamist actors eschewing political participation for two reasons: first, due to a lack of political ambitions inside Syria, for conservative ulama and the armed Islamists who, having failed to topple the Assad regime during the 1979-1982 uprising, migrated to foreign lands of Jihad; second, 
because of an exclusive conception of politics that is little concerned with relevance beyond core constituencies, hence does not need nationhood as a common ground for crossideological alliances. The latter logics was well illustrated after 2011: the popular revolution having initially conferred a hegemonic status on Syrianhood, the latter was embraced by those Islamists who were ready to reach out to unlike-minded revolutionaries, ${ }^{6}$ whereas it was rejected by those who preferred to go it alone.

In the first section of this chapter, I account for the persisting loyalty of the SMB to Syriacentric Arab nationalism from the group's inception in 1946 to the publication of its latest detailed political platform in 2004. In the second section, I analyse the nature and drivers of traditionalist and militant rejection of nationalism from the 1960s until the eve of the 2011 revolution. The latter is the focus of the last section, in which I leave aside the Islamic State's Pan-Islamic project, discussed elsewhere in this volume, to concentrate on the gradual enshrinement of Syrianhood among a broad segment of the Islamist spectrum throughout the conflict.

\section{The Syrian Muslim Brotherhood's Syria-centric Arab nationalism}

From its inception, the SMB defined nationhood in a way that was at the same time distinctly Syria-centric, and primarily shaped by the ideal of Arab - rather than Islamic - unity. In 1947, SMB leader Mustafa al-Siba 'i rejected Jordan's project of "Greater Syria" in the name of aspirations to the reconstitution of "natural Syria", which unlike the Hashemite unity scheme, should include Alexandretta, Lebanon, and the whole of Palestine. Al-Siba 'i also opposed King Abdallah's ambitions because their divisive character put "Arab cooperation" at risk. ${ }^{7}$ In 1949, likewise, al-Siba'i rejected another Hashemite project of Syrian-Iraqi unity by stressing both the reality of Syria's statehood, and the ideal of Arab unity: "We support all Arab countries; we want the cancellation of the artificial borders, and it is natural that we should begin with a union with Iraq. But we don't want such a union to constrain the free and independent state of Syria." 8 The same year, the SMB-led Islamic Socialist Front ran for parliamentary elections with a distinctly Arab nationalist platform: "Strengthening ties between Arab states in all domains" topped the list of foreign-policy priorities, whereas "enhancing cooperation among Islamic states" came only fourth and was confined to matters of "culture and economy". 9

The SMB's defence of Syrian sovereignty against Hashemite ambitions derived from the Islamists' perception of the Greater Syria project as "an obvious tool in the hands of British imperialism." ${ }^{10}$ Hostility to the monarchies of Jordan and Iraq also resulted from a preference for the republican system, which the SMB made a core component of Syrianhood: "Syria in its current borders has long enjoyed the benefits of a republican system", al-Siba 'i emphasised, "and it strongly refuses to embrace another regime". ${ }^{11}$

As for the SMB's approach to supranational unity schemes, it was shaped by the hegemonic status pan-Syrian and Arab nationalisms had acquired in Syrian politics, to the extent of rendering any alternative option irrelevant. The Islamists were not opportunistically embracing an alien ideology: in Syria, Arabism had deep roots among reformist Islamic circles, ${ }^{12}$ some members of which were direct forefathers of the SMB. For instance, while studying in Cairo, al-Siba ' $i$ made his debuts as a columnist with al-Fath, the journal of his mentor Muhibb al-Din al-Khatib (1886-1969), ${ }^{13}$ a Syrian exile who in 1906 had founded the "first true Arab society of the twentieth century", ${ }^{14}$ the Arab Renaissance Society. ${ }^{15}$ During the First World War, al-Khatib joined Sherif Hussein in Mecca, then the short-lived administration of his son Faysal in Damascus, alongside Sheikh Kamil al-Qassab (1853- 
1954), another early Arab nationalist who, in 1937, would found the first distinctly political Islamic organisation in the country, the Association of Ulama. ${ }^{16}$

Even less intuitive than the Arab nationalist orientation of the early SMB was the remarkable durability of this orientation. Despite Nasser's persecution of the Muslim Brotherhood in Egypt, the SMB welcomed the establishment of the United Arab Republic (UAR) in 1958. ${ }^{17}$ Pan-Arab ideals were more hegemonic than ever at the time, as illustrated by the publication, of a book in which the SMB's second most important figure defended the compatibility between Islam and Arab nationalism. ${ }^{18}$ Even more important, perhaps, was the fact that Nasser was perceived as a bulwark against Communism by conservative forces in Syria. ${ }^{19}$

Yet, when most of such conservative forces reacted to Nasser's socialist reforms by engineering the secession (infisal) from the UAR three years later, the SMB refrained from endorsing their move. This was because by that time, the social base of the SMB largely overlapped with that of the Nasserite movement. In Syria (as in Lebanon and Iraq), the latter appealed to members of the conservative Sunni Middle class who were wary of the Ba'th's radical agenda in terms of economic policies and secularism. At the apex of Arab nationalism, they saw Nasserism as a more relevant and credible response to this challenge than the Islamist movement. For a while, this made the SMB partly redundant, as illustrated by a stream of defections to the Nasserites. ${ }^{20}$

From the 1970s onwards, conversely, many Islamists in Syria and elsewhere started to reject Arab nationalism as an ideology now largely conflated with secularist dictatorship. ${ }^{21}$ The SMB was not immune to that trend, as will be explained in the next section. Yet, in the SMB's official platforms, commitment to Pan-Arabism survived not only the advent of the Syrian Ba'thist regime in 1963, but also the destruction of the SMB's domestic apparatus at the hands of the same regime in the early 1980s, and the gradual obsolescence of Arab nationalism from the 1970 s onwards.

In 1980, that is, thirteen years after the 1967 war sparked the decline of Pan-Arabism, both Assad and the SMB were still trying to outbid each other through displays of Pan-Arab commitment. In March of that year, faced with a looming Islamist insurgency and unrest among conservative segments of society, the regime reinstated the flag of the UAR as Syria's national symbol. ${ }^{22}$ In following November, the SMB released a platform, the Proclamation and Programme of the Islamic Revolution in Syria, that retained the Arab nationalist tenets of the origins. "Arab unity" topped the list of foreign-policy priorities: it was an "urgent duty", the document argued, to abolish "the artificial boundaries that separate the parts of one country and the people of one nation". By contrast, "cooperation with the Islamic peoples" only came third, after the liberation of Palestine. ${ }^{23}$

The SMB initially enthused over Iran's Islamic revolution, ${ }^{24}$ and had Khomeini decided to support them against Assad, they would probably have adopted a more decidedly Pan-Islamic agenda. But the new leaders in Tehran sided with the Ba'thist regime, and the SMB was left with predominantly Arab nationalist partners, with whom calls for Arab unity provided a convenient common ground. Syria's non-Islamist opposition remained dominated by Arab nationalists such as the group of Akram al-Hawrani, Jasim 'Alwan's Nasserites, and Ba'thist dissidents backed by what was then the most ambitious and powerful torchbearer of Arab nationalism, namely, Saddam Hussein's Iraq. By 1982, the SMB and the aforementioned Arab nationalist opponents were formally allied within the Bagdad-based National Alliance for the Liberation of Syria. ${ }^{25}$

Similar factors account for the fact that another quarter of century later, in 2004, the SMB's updated platform, the Political Programme for Future Syria, still featured Arab nationalist phraseology: "the Arab regional states (al-duwal al-qutriyya) are parts of one same body", the 
SMB asserted, and they "should form one same political entity (called) the United Arab States". Islamic unity was given greater attention than in previous SMB platforms, but this was made inconsistently (sometimes envisioned as a state merger, sometimes as a mere "bloc"), and the concept of Caliphate was still entirely absent. ${ }^{26}$

Emphasis on Arab unity actually still made sense in 2004. Arab popular sentiments were undergoing some revival in the context of the al-Aqsa Intifada and US invasion of Iraq, both of which had provided the Syrian regime with the opportunity to boost its Arab nationalist credentials. Arab nationalists also remained key partners for the SMB within the crossideological opposition coalitions that the Islamists joined in the following years: Nasserite Hassan 'Abd al-'Azim and Akram al-Hawrani's daughter Fida' were leading figures in the Damascus Declaration (2005), and dissident Ba'thist and former vice-president 'Abd al-Halim Khaddam co-chaired the Syrian Salvation Front (2006). ${ }^{27}$

Over more than six decades, thus, the SMB's definition of the ideal polity remained remarkably consistent in its Syria-centric and Arab nationalist approach. It proved relatively immune not only to the general decline of Arab nationalism, but also to a growing rejection of nationalism among traditionalist and militant Islamists alike.

\section{Against nationalism: radicals and traditionalists}

The SMB's flexible approach to nationalism was challenged from the onset by the Islamic Liberation Party (hizb al-tahrir al-islami, hereinafter HTI), a radical (yet non-violent) organization founded in Jerusalem in 1953 by judge Taqi al-Din al-Nabhani, who settled in Damascus two years later. Nabhani's decision to establish HTI coincided with his own intellectual divorce with Arab nationalism, which he branded as an ideology invented by colonial powers, and promoted by Christian missionary organisations, to divide Muslims. Even Pan-Islamism (al-jami 'at al-islamiyya) did not find favour with Nabhani's eyes, because its loose cooperative form that was fashionable at the time was seen by him as another colonial invention to distract Muslims from the need to restore the Caliphate. ${ }^{28}$ Tellingly, the first reported arrest of HTI members in Syria occurred while they were distributing leaflets disparaging as "useless" the 1956 Damascus Islamic Congress organised by the SMB in support of Palestine and Algeria. ${ }^{29}$ HTI's maximalist position in matters of Islamic unity was function of its rejection of participation in the democratic system: since unlike the SMB, HTI did not have to concern itself with winning elections and allying with non-Islamist forces, it could avoid paying even lip service to the dominant trend in the identity politics of the time.

HTI did not pose a lasting threat to the SMB: the advent of the UAR in 1958 made the party even less ideologically relevant in a context of Arab nationalist effervescence, and a target for repression by the new authoritarian regime. ${ }^{30}$ HTI's leadership relocated to Beirut, while retaining only a modest, albeit lasting, underground presence inside Syria. A more robust challenge to the SMB's blend of Islamism and Arabism came from the mainstream and more specifically from traditional ulama.

In late Mandate and early postcolonial Syria, the ulama had not pushed for an Islamic alternative to the dominant Syrian irredentism and Arab nationalism. By that time, the country's religious elite had come under the domination of newcomers who had little ties to, and nostalgia for, the Ottoman era. Moreover, The close alliance between this newly established religious elite and the notables who dominated the parliamentary system gave the former little reason to challenge the latter on the issue of nationalism which, unlike the preservation of orthodoxy and public morality, was not a core concern for the ulama. ${ }^{31}$ However, the rise of the aggressively secularist Ba'th party, then its 1963 military coup, gave Arab nationalism a bad name among the Sunni 
conservatives, who unlike the SMB, were not concerned with political relevance and crossideological alliances. Among them was Sa'id Ramadan al-Buti, a Professor at the Faculty of Sharia in Damascus. Al-Buti's hostility towards nationalism had personal roots, since he was the son of a Kurdish scholar from Cizre (Turkey) who had sought refuge in Damascus in the early 1930s after fleeing repression by the Turkish republic of Mustafa Kemal.

Al-Buti's scathing indictment of nationalism, and rehabilitation of the Ottoman Caliphate, had much in common with HTI's narrative, with even more conspiratorial overtones. In That is how nationalism was born, a public talk that was published as an article in $1963,{ }^{32}$ al-Buti explained that nationalism was promoted in Ottoman lands by British imperialists, Zionists and Freemasons to undermine the Caliphate and take Palestine. These designs were courageously, but in the end unsuccessfully, resisted by Sultan 'Abd al-Hamid II and his Pan-Islamic policy. "Zionists attempts (at dismantling the Ottoman Empire)", al-Buti wrote, "bore their fruits in our country, unfortunately ... which led to the establishment of secret societies, and the emergence of ideas that called for reviving nationalist chauvinism and for revolting against Turkish rule." This narrative spread all the more easily that in the following decades, al-Buti became Syria's foremost Islamic scholar, and that in exchange for his support, Hafez and Bashar al-Assad granted him considerable leeway to operate. ${ }^{33}$

Al-Buti's account of the birth of nationalism eventually became standard in Syrian mosques. ${ }^{34}$ It resonated with the anti-nationalist views of two other non-Arab figures who were among the most widely read Islamist authors in 1960s-1970s Syria, because their writings were spared the ban imposed by the state on most publications by Muslim-Brotherhood members. ${ }^{35}$ British India-born Abu al-Hassan Ali al-Nadwi and Abu al-A'la al-Mawdudi had both opposed the rise of Muslim and Hindu nationalism in their homeland, and the subsequent Partition of the subcontinent. ${ }^{36}$ Likewise, and contradicting in this the SMB's official line, both emphasised the inherent incompatibility between Arab nationalism and Islam. ${ }^{37}$

Anti-nationalism being on the rise region-wide, ${ }^{38}$ it inevitably affected the SMB. As shown above, the latter never formally broke with Arabism, but leading figures of the group did. In his 1971 book Soldiers of God, Hama-born SMB ideologue Sa'id Hawwa skipped the step of Arab unity by calling for the restoration of the Caliphate and the establishment of the worldwide state of Islam. ${ }^{39}$ In 1987, fellow SMB scholar Sheikh Abdallah Nasih 'Alwan published an account of the origins of Arab nationalism that largely drew on al-Buti's theory of a Zionist-masonic conspiracy. ${ }^{40}$

For Syria's established scholars as well as for the exiled SMB, the rejection of nationalism had limited practical, or even potential, implications. Secular Turkey being an unappealing partner at the time, Arab countries remained their main horizon beyond Syrian borders: it was in Lebanon, and Iraq, that they carried out missionary activities; in Cairo's al-Azhar university that they sought postgraduate degrees in Islamic studies; in Gulf countries, Jordan and Iraq, that they found employment, obtained political asylum, and were given support for anti-regime activities. $^{41}$

Only in the very last years of the pre-2011 era did the mainstream ulama's "Ottomanostalgia" found some political use - for the Ba'thist regime. Bilateral Syrian-Turkish relations improved markedly throughout the first decade of the new century, a trend driven by Turkey's booming economy and anti-PKK cooperation. ${ }^{42}$ In Syria, rapprochement with Ankara entailed a partial rehabilitation of the long-reviled Ottoman era. By 2011, for instance, one of Aleppo's ancient madrasas was being restored to host a Turkish-funded museum of the city's Ottoman past. ${ }^{43}$ Mainstream ulama were all the more willing to encourage this endeavour that in the meantime, the AKP government had steered Turkey away from secularism. In 2009, for instance, head of the al-Fath Islamic Institute in Damascus Sheikh Husam al-Din Farfur congratulated Bashar al- 
Asad for his recent visit to Turkey by emphasising that the two countries were bonded by "the doctrine of Islam, and almost half a millennium of common history." 44 The following year, in a re-edition of a sermon given by Kurdish-born Islamic thinker Sa'id Nursi in 1911 at Damascus' Umayyad mosque, al-Buti described the new friendship between the two states as "the premise of the coming Islamic unity", a project which, if it succeeded, would mean that "the only thing we lost with the disappearance of the Caliphate was its name."

In the meantime, on the fringe of Syria's Islamic scene, radical actors had put anti-nationalist views in the service of an actual political project, namely, the creation of the global Jihadi movement. The Syrian Islamists' story with transnational armed struggle was an old one, but until the 1980s, it was confined to Syria's Arab vicinity: an SMB expeditionary force participated in the 1948 Arab-Israeli war, ${ }^{46}$ and in the late 1960s, hardliners like Marwan Hadid and 'Abd al-Sattar al-Za'im individually joined the small Islamist component in the Fedayin movement that carried out cross-border operations against Israel from Jordan. ${ }^{47}$ Following the death of Hadid in detention in Syria in 1976, al-Za'im and his brothers in arms formed their own organization separate from the SMB, the Fighting Vanguard, and sparked the Islamist insurgency of 1979-82.

Following their defeat at the hands of the Assad regime, surviving Fighting Vanguard members joined the anti-Soviet jihad in Afghanistan at the invitation of Palestinian Islamist 'Abdallah 'Azzam. ${ }^{48}$ As Thomas Hegghammer has shown, 'Azzam's unprecedented initiative to recruit Arab Islamists for an armed conflict far from the Arab world was rooted in a broader ideological shift that occurred in the 1970s, namely, the promotion of worldwide Muslim solidarity by Saudi-based, Muslim-Brotherhood operated international Islamic organisations like the Muslim World League. ${ }^{49}$ The experience of the Afghan jihad and its aftermath further reinforced the pan-Islamic ideals of Syrian Islamist militants: they were now part of a multi-national vanguard which, after the Soviet withdrawal from Afghanistan in 1989, pursued transnational armed struggle in other non-Arab Muslim lands like Bosnia and Chechnya then, at Usama bin Laden's behest, against US interests worldwide.

The Jihadis' promotion of a Pan-Islamic agenda went naturally hand in hand with a demonization of nationalism that is found, for instance, in 'Azzam's Arab Nationalism, a text whose lasting influence is illustrated by its partial reproduction in The Call to Global Islamic Resistance, a lengthy treaty released in 2004 by Abu Mus'ab al-Suri (Mustafa Setmariam Nasar), a Fighting Vanguard veteran and leading Jihadi theoretician, shortly before his arrest in Quetta, Pakistan, in 2005. ${ }^{50}$ In substance, 'Azzam's account was similar to that of al-Buti, as it highlighted the Western imperialist/Christian/masonic origins of nationalism. It was better sourced, but relying extensively on George Antonius' classical Arab Awakening, it ignored the role played by proto-Islamists like al-Khatib and al-Qassab at the onset of Syria's Arab nationalist movement. ${ }^{51}$

On the eve of the 2011 revolution, Jihadis had little reasons to revise their anti-nationalist views. When they had finally been able to bring back their struggle into the Arab heartlands thanks to the 2003 US occupation of Iraq, they had rapidly found themselves fighting a vicious sectarian war against Iraqi Shias. They were following in this the explicitly antinationalist agenda of Al-Qaeda in Iraq's leader Abu Mus'ab al-Zarqawi, for whom (Sunni) religious creed was the only legitimate political bond. ${ }^{52}$ Yet, Syria's uprising, and the ensuing conflict, sparked a deep divide among Islamist radicals regarding the question of nationhood.

\section{The 2011 uprising and the enshrinement of Syrianhood}


In July 2014, the Islamic State staged the physical destruction of segments of what it presented as the "Sykes-Picot border" that separated Syria from Iraq. Provinces of ISO's newly-proclaimed Caliphate stretched across the former dividing line between the two countries, while other "provinces" would later be established as far as Nigeria and Afghanistan. The Syrian war, thus, was the occasion for Jihadi militants recruited from the five continents to conceive and implement the most radical kind of anti-nationalist agenda. Yet, for other Islamists, the conflict was, on the contrary, an occasion to strengthen their belief in, or discover, the legitimacy of the national framework.

The first and main driver of ideological revisions among Syrian Islamists was the revolutionary impetus of 2011, which bolstered the legitimacy of Syrianhood in the eyes a broad range of actors. The political and military forces that acknowledged the March 2011 popular uprising as the founding moment of their action, or at least as a major symbolic turning point, inevitably had to pay homage to those responsible for this sea change: the Syrian people, who took the streets, then took up arms, without direction from any political organisation. Conversely, those political forces that rejected the Syrian national framework, that is, transnational Jihadis and the Kurdish (yet "post-nationalist") PYD ${ }^{53}$ were also those that did not frame their struggle as a continuation of the 2011 Syrian revolution: the former refrained from using the term "revolution" altogether until 2016, and preferred the expression "jihad of Sham"; 54 as for the latter, it hailed the "Rojava revolution" that started in 2012, when the partial withdrawal of regime forces allowed for the PYD's experience with selfgovernance in northern Syria. ${ }^{55}$

Another consequence of the Arab Spring, for those who acknowledged its significance, was at the same time to bolster a short-lived sense of solidarity among Arab peoples, and to eliminate whatever legitimacy remained for top-down Arab unity schemes, which were inextricably associated with the execrated postcolonial authoritarian regimes. By late 2011, Syrian opponents, including the SMB, unhesitantly traded what was now known as "the regime's flag" for the country's pre-Ba 'thist banner, itself renamed "flag of the revolution" ( 'alam al-thawra). That "tyranny's bloody standard" was not only the symbol of Assad's Syria, but also the former flag of the UAR, went almost unnoticed.

More remarkable than the adoption of the revolutionary flag by the SMB, which as we know, had always felt comfortable with national symbols, was its defence by more doctrinaire Islamists against criticisms from Jihadi proponents of the replacement of the flag of the revolution with the black banner bearing the Islamic profession of faith (shahada).

Throughout 2012, the rise of Jihadi groups such as the Nusra Front among the insurgency resulted in controversies and occasional fistfights in rebel-held areas over the flag. In this debate, proponents of the flag of the revolution received the support of Hay'at al-Sham alIslamiyya, an activist Salafi missionary organisation that provided religious guidance for the Syria Islamic Liberation Front (SILF), the largest rebel coalition in 2012-13. Hay'at al-Sham argued that there was no such thing as a prescribed "Islamic flag", and that national flags were lawful as long as they were raised while pursuing legitimate goals such as the Syrian rebels' self-defence against regime aggression. ${ }^{56}$

Further right on the Islamist spectrum, Syrianhood also found advocates, albeit more ambiguous ones, among Ahrar al-Sham, the largest insurgent faction apart from the Islamic State. Ahrar al-Sham did not officially endorse the revolutionary flag until 2017, as will be explained below, but it was careful, from the onset, to present itself as independent from any transnational organisation (read, by 2012, al-Qaeda), and solely concerned with Syria in terms of military operations. In December 2012, Ahrar al-Sham assembled a coalition of likeminded factions called the Syrian Islamic Front (SIF), ${ }^{57}$ a name that contrasted with the Nusra Front's preference for the pre-modern (hence pre-nation-state) term "Sham". ${ }^{58}$ Abu Basir al- 
Tartusi, another revisionist Jihadi, emphatically praised the "Free Syrian Army" and defended it against the criticisms of hardline Jihadis, among which the accusation of not fighting under a properly "Islamic" banner. ${ }^{59}$ Between the Syrian people in arms and the transnational Jihadi vanguard, al-Tartusi sided with the former, a choice that would also eventually lead him to embrace the flag of the revolution.

For revisionist Jihadis, and even for more mainstream Islamists, the process leading to the full acceptance of Syrian national symbols was not a linear one, as it witnessed a hiatus in 2013. That year, the insurgency at large underwent a process of Islamist radicalisation under the influence of several factors: first, the rise of Jihadi factions and particularly of the Islamic State in Iraq and Sham; second, intervention in the war of Iran-sponsored foreign Shia militias like the Lebanese Hezbollah; third, the military coup against the Muslim Brotherhood government in Egypt, which coincided with the takeover of the Syrian National Coalition by anti-Islamist Saudi clients; fourth, US president Obama's decision to walk back on his threat to retaliate against the Assad regime following the Ghuta chemical attack in August.

In 2013, thus, a growing number of rebel factions were created that did not display the revolutionary flag, and others removed it from their logo, such as the SILF-affiliated Suqur alSham and the SMB-linked Sham Legion (faylaq al-sham). ${ }^{60}$ Likewise, Hay'at al-Sham alIslamiyya removed the revolutionary flag from the cover of its magazine Nur al-Sham one year after issuing the aforementioned fatwa in defense of that flag. ${ }^{61}$ The decline of national symbols to the benefit of Pan-Islamic keywords was further illustrated in November 2013 by the decision of the SILF and SIF to merge into a newly formed "Islamic Front", whose name thus made no reference to Syria, and whose charter was titled "Project of the Islamic Community" (mashru' umma). ${ }^{62}$

The rhetorical shift away from Syrianhood was partly aimed at seizing new opportunities. In the spring of 2013, Hezbollah's intervention in the conflict sparked a wave of transnational Sunni solidarity with Syria's beleaguered opposition against its Shia enemies. That trend reached its peak in June 2013 with a Pan-Islamic conference held in Cairo, during which such high-profile clerics as Qatar-based Muslim Brotherhood's chief scholar Yusuf al-Qardawi and Saudi preacher Muhammad al-"Arifi endorsed a statement calling on all Muslims to support jihad in Syria. ${ }^{63}$ Speaking at the conference, Ahrar al-Sham's leader Hassan 'Abbud called for "going past the narrow borders of the nation-state". ${ }^{64}$

This moment of pan-Islamic enthusiasm did not last. Abroad, mainstream non-state mobilization for Syrian insurgents subsequently waned as a result of anti-Islamist repression in Egypt and Gulf monarchies, and because of fatigue in the face of an increasingly protracted and fragmented conflict - by 2014, the Islamic State and other rebels were at war with each other. Inside Syria, the theme of nationhood underwent a revival in reaction to increasingly tense relations with the Nusra Front. Throughout 2014, Ahrar al-Sham showed growing signs of pragmatism, partly as a result of combined US-Qatari pressures, partly due to internal influence such as that of Ahrar al-Sham's chief scholar Abu Yazan al-Shami, who seized the context of all-out war with the Islamic State to criticize key tenets of Salafi-Jihadi ideology. In May, Ahrar al-Sham joined mainstream factions in signing the Revolutionary Honor Covenant, a soft-worded document that framed the struggle as a strictly Syrian one. During the summer, likewise, Ahrar al-Sham joined the Wa 'tasimu ("Hold on") initiative, which aimed at uniting most factions under a single political umbrella while excluding the Nusra Front. ${ }^{65}$ In the face of the latter's hostile responses to these gestures, Ahrar al-Sham leaders justified their break with Jihadi purism in terms that simultaneously drew on, and enshrined, the idea of Syrianhood. "This is our country and our revolution", Abu Yazan insisted, while making fun of his detractors' obsession with the Sykes-Picot borders. ${ }^{66}$ Likewise, while explaining to his fighters why their group had chosen not to be part of al-Qaeda or any other 
transnational project, 'Abbud emphasized that such external models did not fit the specificities of the "Syrian reality" ${ }^{67}$

From late 2014 onwards, tensions between the Nusra Front and other rebel factions turned to recurrent military incidents. In March 2015, this context sparked a broad-based anti-Jihadi reaction that gave rise to online and street-level campaigns in support of the flag of the revolution. Rebel commanders from the Sham Legion and Ahrar al-Sham acted upon the slogan "Raise the flag of your revolution" that was propagated by civilian activists. ${ }^{68}$ In addition to rivalry with the Nusra Front, another driver behind the revival of the national symbol was the rebels' desire to improve their public image: first, while they seemed to have good chances of winning the war in mid-2015, ${ }^{69}$ then when, after the Russian intervention, they had to close ranks under international pressures to participate in the resumption of the Geneva process in a position of weakness. The spokesman of the Islam Army, a powerful Salafi faction from Damascus, first appeared on television besides the revolutionary flag in March 2016. ${ }^{70}$ As for Ahrar al-Sham, it took it another year, and a large-scale military conflict with the Nusra Front, now renamed Levant Liberation Committee (hay'a tahrir al-sham), to officially endorse the revolutionary flag, pledge allegiance to a "national" (watani) revolutionary project, and support the Syrian Interim Government's initiative to reorganize rebel factions into a Turkish-backed "Syrian National Army".71

Another, parallel, dynamics that encouraged Syrian Islamists to extol Syrianhood was the expansion across northern Syria of the US-backed Kurdish PYD, which in March 2016 proclaimed the establishment of a federal system. "The division of Syria is a red line", Ahrar al-Sham leader Muhannad al-Masri declared on Al Jazeera. ${ }^{72}$ Sixty-nine other rebel factions, including the Army of Islam and the Sham Legion, issued a joint statement calling for the preservation of "the unity of Syria's land and people". ${ }^{73}$ Likewise, a map of Syria featured on each cover of the three issues of Hay'at al-Sham al-Islamiyya's magazine Nur al-Sham released after March 2016. ${ }^{74}$

By 2018, even hardline Jihadis from the former Nusra Front were not completely spared by national dynamics. In a way, they had never been: the April 2013 divorce between the Nusra Front and the Islamic State in Iraq and Sham was a break between a predominantly Syrian-led organisation, on the one hand, and an Iraqi-led one, on the other hand. In 2014-15, when tensions emerged within the Nusra Front between hawks willing to match the challenge from the Islamic State through displays of Jihadi purism, on one side, and doves attached to the preservation of cordial relations with mainstream rebel factions, on the other side, the latter were reportedly labeled "regionalists" (qutriyun) by their detractors, a term reminiscent of the 1960s' rivalry among the Ba'th party between Pan-Arab "nationalists" (qawmiyyun) and Syriacentered "regionalists". 75

Although the Nusra Front's "regionalists" were purged at the time, their approach was partly rehabilitated from early 2016 onwards, when the group (subsequently renamed Jabha Fath alSham then Hay'a Tahrir al-Sham) started to praise the "blessed revolution" of 2011 and proclaim its independence from any foreign organisation, that is, al-Qaeda. Through this shift, the Jihadis aimed to capitalise on the new context brought upon by the Russian intervention, that is, rebel defeats and a looming abandonment of the insurgency by its state sponsors. Acknowledging its failure to substitute the frame of "revolution" for that of "jihad" among the pro-opposition public, the group now sought to rally support outside its core constituency by portraying itself as the last genuine revolutionary force. ${ }^{76}$ The ultimate step in this strategy was the establishment by HTS, in November 2017, of a purportedly independent, yet surrogate, 
civilian administration for Idlib called "Syrian Salvation Government" and whose president gave his inaugural speech standing beside the flag of the revolution. ${ }^{77}$

These moves were perceived by al-Qaeda's leader Ayman al-Zawahiri for what they were, that is, a break with Jihadi internationalism and a de facto embrace of national boundaries. AlZawahiri responded by emphasizing the need for Islamic unity, and scolding the drive to divide global jihad along national lines: "there are some who want to push us back behind the lines of division drawn by disbelieving occupiers ... Pakistan for Pakistanis, Syria for Syrians, Palestine for Palestinians ... in the interest of whom, may we ask?"78 This was definitely not in the interest of al-Qaeda, which had lost his Syrian affiliate, and would subsequently have to rely on a handful of loyalists to rebuild an organisational foothold in Syria. ${ }^{79}$ But many, among hardline Islamists, had obviously concluded that it was in their own interest to blend into, rather than opposing, national dynamics.

\section{Conclusion}

Throughout its seven decades of existence, the SMB's approach to the question of Syria's borders has been determined by the strategic choice to participate in the country's political system alongside other forces. In the late 1940s, it was in defence of Syria's parliamentary republic that the organisation opposed Jordanian and Iraqi ambitions. Subsequently, the SMB remained committed to the Arab nationalist ideals of the late-Ottoman proto-Islamists out of a quest for relevance in the context of Nasser's growing popularity, particularly among Syria's conservative opinion. Likewise, for half a century after the Ba'thist coup of 1963, the SMB considered that returning to Syrian politics required to remain in tune with the Arab nationalist ideas which, although increasingly vilified by conservative ulama and Islamist militants, were still upheld by both the regime and its main non-Islamist opponents. Only with the 2011 revolution, which sanctioned the primacy of Syrianhood among the mainstream opposition, did Pan-Arabism lost any relevance for the SMB. The idea of Syrian borders as a legitimate framework for action also gained acceptance among formerly hostile Islamists such as Ahrar al-Sham's former Jihadis. Like the SMB, Islamist newcomers to nationhood acknowledged the role of the Syrian people in bringing about a new political era, and consequently envisioned politics in terms of cross-ideological alliances. On the contrary, diehard Pan-Islamists such as the Islamic State paid no heed to popular agency and sought exclusive political power through the wholesale elimination of their competitors.

After it climaxed in 2014 with the proclamation of the Islamic States' Caliphate, militant Sunni Pan-Islamism has taken a back seat in Syria with the recapture of most territories formerly controlled by the Islamic State, and HTS' cautious fallback on a local agenda. History does probably not stop there, however. The Syrian population now consists of almost six million refugees, most of which are likely to become a permanent diaspora. Yet, in the case of Palestinian refugees in Lebanon, it has been argued that double exclusion-physically, from the homeland, and politically, from host countries - made militant Islamic internationalism an appealing option, ${ }^{80}$ and other authors have highlighted the link between exile and the outsized contribution of Palestinian ideologues to the Jihadi movement. ${ }^{81}$ The same causes do not always produce the same effects, but if they eventually do among Syrian refugee communities, this should not come as a surprise.

${ }^{1}$ Olivier Roy, The Failure of Political Islam (Harvard University Press, 1994).

${ }^{2}$ Ghada Hashem Talhami, "Syria: Islam, Arab Nationalism and the Military", Middle East Policy 8/4 (2001), 111. 
${ }^{3}$ Israel Gershoni and James P. Jankowski, Redefining the Egyptian Nation, 1930-1945, (Cambridge: Cambridge University Press, 1995), 54-96; Sami Zubaida, "Islam and Nationalism: Continuities and Contradictions", Nations and Nationalism 10, no.4 (2004): 407-20.

${ }^{4}$ Sam Heller, “Ahrar al-Sham's Revisionist Jihadism”, War on the Rocks, 30 September 2015, https://warontherocks.com/2015/09/ahrar-al-shams-revisionist-jihadism/.

${ }^{5}$ Raphaël Lefèvre, Ashes of Hama: The Muslim Brotherhood in Syria (London: Hurst, 2013).

${ }^{6}$ Whereas acceptance of the Syrian national framework is thus closely related to acceptance of a level of political pluralism, it does not necessary imply the embrace of a cross-sectarian agenda. On the coexistence of nationalism and sectarianism on both sides of the Syrian civil war, see my Thomas Pierret, « Syrie: État sans nation ou nation sans État? », in Vers un nouveau Moyen-Orient? États arabes en crise entre logiques de division et société civile, eds. Anna Bozzo and Pierre-Jean Luizard (Rome: Roma Tre, 2016), 181-92.

${ }^{7}$ Johannes Reissner, Ideologie und Politik der Muslimbrüder Syriens. Von den Wahlen 1947 bis zum Verbot unter Adib aš-Šisakli 1952 (Freiburg: Klaus Shwarz, 1980), 410-15.

${ }^{8}$ Joshua Teitelbaum, "The Muslim Brotherhood and the 'Struggle for Syria', 1947-1958 Between Accommodation and Ideology," Middle Eastern Studies 40/3 (2004): 141.

${ }^{9}$ Reissner, Ideologie und Politik der Muslimbrüder Syriens, 416.

${ }^{10}$ Reissner, 411.

${ }^{11}$ Reissner, 412.

${ }^{12}$ David Dean Commins, Islamic Reform: Politics and Social Change in Late Ottoman Syria (Oxford: Oxford University Press, 1990); Itzchak Weismann, Abd Al-Rahman Al-Kawakibi (London: Oneworld, 2015); James Gelvin, Divided Loyalties: Nationalism and Mass Politics in Syria at the Close of Empire (Berkeley: University of California Press, 1999).

13 'Adnan Zarzur, Mustafa al-Siba'i. Al-da'iya al-mujaddid (Mustafa al-Siba'i: The Preacher and Renewer) (Beirut: Dar al-Qalam, 2000), 89-93.

${ }^{14}$ Eliezer Tauber, The Emergence of the Arab Movements (Oxon: Routledge, 1993), 43; 96.

${ }^{15}$ On al-Khatib and Arabism, see also Commins, Islamic Reform; Nimrod Hurvitz, "Muhibb ad-Din al-Khatib's Semitic Wave Theory and Pan-Arabism”, Middle Eastern Studies 29, no. 1 (1993): 118-34.

16 Thomas Pierret, Religion and State in Syria: The Sunni Ulama from Coup to Revolution (Cambridge: Cambridge University Press, 2013), 166-167

${ }^{17}$ Jamal Barut, "Suriyya: usul wa ta'arrujat al-sira 'bayn al-madrasatayn at-taqlidiyya wa alradikaliyya (Syria: origins and twists and turns of the conflict between the traditional and radical schools)," in al-Ahzab wa-l-harakat wal-jama 'at al-islamiyya [Islamic parties, movements, and groups], ed. Jamal Barut and Faysal Darraj (Damascus: Arab Center for Strategic Studies, 2000), 262.

${ }^{18}$ Muhammad al-Mubarak, Al-ummat al- 'arabiyya fi ma'raka tahqiq al-dhat (The Arab Nation in the Battle for Self-Realisation) (Damascus: Dar al-Fikr, 1959).

${ }^{19}$ Pierret, Religion and State in Syria, 176

${ }^{20}$ Thomas Pierret, "Islamist-Secular Cooperation: Accounting for the Syrian Exception," in The Dynamics of Opposition Cooperation in the Arab World: Contentious Politics in Times of Change, ed. Hendrik Kraetzschmar (Oxon: Routledge, 2013), 89

${ }^{21}$ Emmanuel Sivan, "Arab nationalism in the age of the Islamic resurgence," in Rethinking Arab Nationalism in the Arab Middle East, ed. James Jankowski and Israel Gershoni (New York: Columbia University Press, 1997), 207-28.

${ }^{22}$ Elie Podeh, "The symbolism of the Arab flag in modern Arab states: between commonality and uniqueness," Nations and Nationalism, 17/2 (2011): 427.

${ }^{23}$ Umar F. Abd-Allah, The Islamic Struggle in Syria (Islamic Publications International, 1983), 260-262. 
${ }^{24}$ Abd-Allah, 184-86.

${ }^{25}$ Pierret, "Islamist-Secular Cooperation," 92-93.

${ }^{26}$ Thomas Pierret, "Le 'Projet politique pour la Syrie de l'avenir' des Frères Musulmans », in La Syrie au présent. Reflets d'une société eds. Baudouin Dupret, Zouhair Ghazzal, Youssef Courbage et Mohammed al-Dbiyat (Paris: Actes Sud, 2007), 737.

${ }^{27}$ Aron Lund, "Divided they stand. An overview of Syria's political opposition factions" (Foundation for European Progressive Studies, 2012), http://www.fepseurope.eu/assets/d6630006-41a1-4549-8d03-3088edc0d6cf/divided-they-stand.pdf.

${ }^{28}$ Jamal Barut, "Hizb al-Tahrir al-Islami (Islamic Liberation Party)," in al-Ahzab wa-lharakat wal-jama 'at al-islamiyya (Islamic parties, movements, and groups), ed. Jamal Barut and Faysal Darraj (Damascus: Arab Center for Strategic Studies, 2000), vol. 2, 61.

${ }^{29}$ Office Arabe de Presse (press survey), 831, VII, 6-7 June 1956.

${ }^{30}$ Office Arabe de Presse, 1114, VIII, 23-26 March 1959 and 1144, VII, 9 September 1959.

${ }^{31}$ Pierret, Religion and State in Syria.

${ }^{32}$ Sa'id Ramadan Buti (al), "Hakadha nasha'at al-qawmiyya (This is how nationalism was born)," Hadarat al-Islam 3/6 (1963): 606-20.

${ }^{33}$ Pierret, Religion and State in Syria.

${ }^{34}$ Personal observations, Damascus and Aleppo 2005-2008.

${ }^{35}$ Pierret, 58

${ }^{36}$ Muhammad Qasim Zaman, The Ulama in Contemporary Islam (Princeton: Princeton University Press, 2002), 163-164; Seyyed Vali Reza Nasr, Mawdudi and the Making of Islamic Revivalism, Oxford (Oxford University Press, 1996), 32; 84-85.

${ }^{37}$ Abu al-Hassan Ali al-Nadwi, Al- 'arab wal-islam (The Arabs and Islam) (Beirut: al-Maktab al-Islami, 1969), 39; Abu al-A'la al-Mawdudi, al-da'wa al-qawmiyya wal-rabita al-islamiyya (Nationalist Ideology and the Islamic Bond) (Beirut: Dar al-'Arabi, 1967).

${ }^{38}$ Sivan, "Arab Nationalism in the Age of the Islamic Resurgence"; Zubaida, "Islam and Nationalism".

${ }^{39}$ Itzchak Weismann, "Sa'id Hawwa and Islamic Revivalism in Ba’thist Syria”, Studia Islamica, 85 (1997): 150.

${ }^{40}$ Abdallah Nasih 'Alwan, Al-qawmiyya fi mizan al-islam (Nationalism in the Balance of Islam) (Cairo: Dar al-Salam, 1987).

${ }^{41}$ Pierret, Religion and State in Syria.

${ }^{42}$ Raymond Hinnebusch and Özlem Tür (eds.), Turkey-Syria Relations: Between Enmity and Amity, (Farnham, Surrey: Routledge, 2013).

${ }^{43}$ Interview with director of Aleppo's Awqaf Library Dr Mahmud al-Masri, Aleppo, 7 July 2010.

44“'Kalimat fadilat al-shaykh al-duktur Husam al-Din Farfur fi ijtima' majlis idara mujamma ' al-Fath al-islami (Speech of his Excellence Sheikh Dr Husam al-Din Farfur at the board meeting of the al-Fath Islamic Academy), 29 September 2009, http://alfatihonline.com/news/d.husam.htm.

${ }^{45}$ Sa'id Nursi, Al-khutbat al-shamiyya (Damascus Sermon) (Damascus: Dar al-Farabi, 2010). 6-7.

${ }^{46}$ Zarzur, Mustafa al-Siba'i, 179-205.

${ }^{47}$ Thomas Hegghammer, The Caravan. Abdallah Azzam and the Rise of Global Jihad (forthcoming book).

${ }^{48}$ Lefèvre, Ashes of Hama, 138-146.

49 Thomas Hegghammer, « The Rise of Muslim Foreign Fighters: Islam and the Globalization of Jihad », International Security 35 (2010): 53-94.

${ }^{50}$ Brynjar Lia, Architect of Global Jihad: The Life of Al-Qaeda Strategist Abu Mus 'ab Al-Suri (New York: Oxford University Press, 2009). 
${ }^{51}$ Abu Mus'ab al-Suri a.k.a. 'Umar 'Abd al-Hakim, Da'wat al-muqawamat al-islamiyyat al'alamiyya (The Global Islamic Resistance Call), (2004), 461 sq.

${ }^{52}$ Gilles Kepel et Jean-Pierre Milelli, Al Qaeda in Its Own Words (Harvard University Press, 2008), 251-67.

53 The 2015 creation of the Syrian Democratic Forces was a concession to Syrian identity forced upon the PYD by its military alliance with non-Kurdish factions, itself a consequence of the group's military expansion into Arab-majority regions thanks to US military support.

${ }^{54}$ See for instance "Al-Julani: Da ish waffarat li-Amrika hujjat al-hujum 'ala al-jihad alshami (Al-Jolani: Daesh provided America with a pretext to attack the Jihad of Sham)," Orient News, 28 September 2014, http://www.orient-news.net/ar/news_show/81500.

${ }^{55}$ See for instance "The Rojava revolution is the beginning of humanity's revolution," $A N F$ News, 14 January 2018, https://anfenglish.com/news/the-rojava-revolution-is-the-beginningof-humanity-s-revolution-24173.

${ }^{56}$ Hay'at al-Sham al-Islamiyya, "Hal hunaka raya muhaddada yajib an yaltazim biha alsuriyyun? (Is there a specific banner by which Syrians have to abide?)," 13 May 2012, islamicsham.org/fatawa/275.

${ }^{57}$ Aron Lund, "Syria's Salafi Insurgents: The Rise of the Syrian Islamic Front," (Swedish Institute of International Affairs, March 2013),

https://www.scribd.com/document/131347537/Syria-s-Salafi-Insurgents-the-Rise-of-theSyrian-Islamic-Front-by-Aron-Lund.

${ }^{58}$ The group's full name is jabhat al-nusra li-ahl al-sham, "Front of Support for the People of Sham".

${ }^{59}$ Joas Wagemakers, « Between Purity and Pragmatism? Abu Basir al-Tartusi's Nuanced Radicalism », in Jihadism and Terrorism. Volume 1: Jihadi Thought and Ideology, eds. Rüdiger Lohlker and Tamara Abu-Hamdeh (Berlin: Logos Verlag, 2014), 30.

${ }^{60}$ The establishment of the Sham Legion in March 2014 was a rebranding of the Civilian Protection Committee, whose logo included the colours of the revolutionary flag.

${ }^{61}$ Nur al-Sham, 10, May 2013.

${ }^{62}$ Aaron Zelin, "Rebels Consolidating Strength in Syria: The Islamic Front,” Washington Institute, 3 December 2013, http://www.washingtoninstitute.org/policy-analysis/view/rebelsconsolidating-strength-in-syria-the-islamic-front.

63 'Min al-Qahira: 'ulama' al-muslimin yad 'awna ila al-jihad fi Suriya (From Cairo: the Muslim Scholars call for jihad in Syria)," Al Arabiya, 14 June 2013,

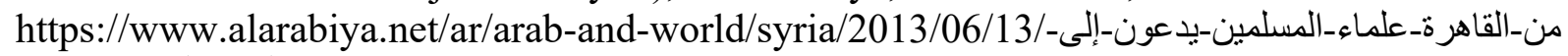
الجهاد_لنصرة-سوريا.html.

64 “'Kalima qa'id haraka Ahrar al-Sham al-islamiyya - mu'tamar mawqif al- 'ulama' min Suriya (Speech by the leader of Ahrar al-Sham Islamic Movement - Conference on the ulama's position on Syria)," Youtube, 14 June 2013, https://www.youtube.com/watch?v=xHQRPB0I890.

${ }^{65}$ Charles R. Lister, The Syrian Jihad: Al-Qaeda, the Islamic State and the Evolution of an Insurgency (London: C Hurst \& Co, 2015), 225-28; 246-47.

${ }^{66}$ Sam Heller, “Ahrar Al-Sham's Abu Yazan: 'It's Our Country and Our Revolution'," Sam Heller // Abu Al-Jamajem // أبو الجماجم (blog), 5 September 2014, https://abujamajem.wordpress.com/2014/09/05/ahrar-al-shams-abu-yazan-its-our-countryand-our-revolution/.

67 “Ahrar al-Sham. Fikr al-Ahrar 'ala lisan mu'assisiha al-sheykh Abu 'Abdallah al-Hamawi rahimahu-llah (Ahrar al-Sham. Ahrar's thought by its founder Sheikh Abu 'Abdallah alHamawi, God have mercy upon him)," Youtube, 3 March 2016, https://www.youtube.com/watch? $v=8$ hZODGrjgKc. This speech is an internal archive that was released by the group after 'Abbud's assassination in September 2014. 
${ }^{68}$ Ahmad Abazeid and Thomas Pierret, « Les rebelles syriens d'Ahrar al-Sham : ressorts contextuels et organisationnels d'une déradicalisation en temps de guerre civile », Critique internationale, 78 (2018): 76.

69 "Islamist rebel leader walks back rhetoric in first interview with U.S. media," McClatchy, 20 May 2015, http://www.mcclatchydc.com/news/nation-world/world/article24784780.html.

70 'Liqa' al-naqib Islam 'Allush al-mutahaddith al-rasmi bi-smi Jaysh al-Islam ma 'a qanat Akit al-turkiyya (Interview of Capt Islam 'Allush, the official spokesman of Jaysh al-Islam, with Turkish channel Akit)," Youtube, 11 March 2016, https://www.youtube.com/watch?v=EFG5ElwHWI4.

${ }^{71}$ Abazeid et Pierret, "Les rebelles syriens d'Ahrar al-Sham », 81-82.

72 "Al-Masri: taqsim Suriya khatt ahmar wal-mufawadat lam tuhaqqi shay'an (Al-Masri : the division of Syria is a red line; negotiations did not achieve anything), Al Jazeera, 16 March

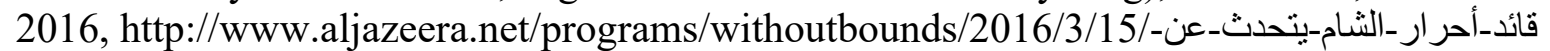
الانسحاب_الروسي

73 "69 fasilan thawriyyan yu 'linuna rafdahum mashari ' taqsim Suriya (69 revolutionary factions proclaim their rejection of the projects that aim to divide Syria)," Eldorar Alshamia, 18 March 2016, http://eldorar.com/node/95882.

${ }^{74}$ Nur al-Sham, no. 41, April 2016; no. 42, November 2016; no. 43, January 2017, https://islamicsham.org/nashrah/year/596.

${ }^{75}$ Aron Lund, "The Nusra Front's Internal Purges", Carnegie Middle East Center, 7 August 2015, http://carnegie-mec.org/diwan/60967?lang=en.http://carnegie-

mec.org/diwan/60967?lang=en

${ }^{76}$ Abazeid et Pierret, « Les rebelles syriens d'Ahrar al-Sham », 79

77 “Al-i 'lan 'an tashkil hukumat al-inqadh fi Idlib that bi-ri'asa Muhammad al-Sheikh (Announcement of the formation of the Salvation Government in Idlib under the presidency of Muhammad al-Sheikh)," Youtube, 2 November 2017, https://www.youtube.com/watch?v=5orACzyc_G8.

78 Thomas Joscelyn, "Zawahiri Lectures on Global Jihad, Warns of National Boundaries," FDD's Long War Journal (blog), 10 June 2017,

//www.longwarjournal.org/archives/2017/06/zawahiri-lectures-on-global-jihad-warns-ofnational-boundaries.php.

${ }^{79}$ Tore Hamming et Peter van Ostaeyen, “The True Story of Al-Qaeda's Demise and Resurgence in Syria," Lawfare, 8 April 2018, https://www.lawfareblog.com/true-story-alqaedas-demise-and-resurgence-syria.

${ }^{80}$ Bernard Rougier, Everyday Jihad. The Rise of Militant Islam among Palestinians in Lebanon (Cambridge: Harvard University Press, 2009).

${ }^{81}$ Thomas Hegghammer et Joas Wagemakers, "The Palestine Effect: The Role of Palestinians in the Transnational Jihad Movement", Die Welt des Islams 53/3-4 (2013): 281-314. 